\title{
Nihilistic Perception of Right as an Axiological Problem of Modern Legal Development
}

\author{
Tatyana V. Shatkovskaya \\ Russian Presidential Academy \\ of National Economy and Public Administration \\ Rostov State University of Economics (RSUE) \\ Rostov-on-Don, Russia \\ shatkovskaya.tv@gmail.com \\ A.N. Pozdnishov \\ Rostov State University of Economics (RSUE) \\ Rostov-on-Don, Russia \\ profepifanova@gmail.com
}

\author{
Tatyana V. Epifanova \\ Rostov State University of Economics (RSUE) \\ Rostov-on-Don, Russia \\ profepifanova@gmail.com
}

\begin{abstract}
This article aims to debunk the pseudo-scientific myths and stereotypes regarding legal nihilism. Authors prove that nihilistic perception of right is objectively a social phenomenon, supported by the controversy of any national cultural dominating idea. Furthermore, the study highlights that legal nihilism presents a societal threat, given the negative perception of particular subjects and groups towards commonly accepted legal values. In overcoming these negative consequences, authors believe that the only possible scenario involves a complete theoretical study of legal nihilism to reveal the actual mechanism of impact, as well as reverse influence of legal nihilism on the social system, which constitutes the main target of the study. The aim of the study is achieved on the basis of a dialectical approach, which involves the research of legal nihilism from the point of view of movement, change and development of legal ideas, taking into consideration the form of development and internal causes. The study has resulted in a range of scientific findings, which are new and have the potential to further develop the investigated problem. Authors have identified stable specific characteristics of legal nihilism and its definition, as well as defined criteria for separating positive and defective understanding of rights, identified stereotypical perceptions about legal nihilism, which do not relate to the essence of the given legal phenomenon, proven the necessity to develop a complex of events to formulate a respectful attitude towards law and rights at the national level.
\end{abstract}

Keywords - legal nihilism, legal axiology, deformation of legal understanding, respect towards right and law, legal values.

\section{INTRODUCTION}

A person cannot physically stop relating oneself to the outside world. The relation is formulated to anything that a person learns, interacts and observes. This relation assumes not only perception and understanding of legal reality, but also its evaluation, which can be both positive and negative. One of the manifestations of latter is legal nihilism, which evolves in the process of psychological-emotional relation of a person or a group of individuals towards law, which directly relates to legal understanding, in particular to legal axiology.

\author{
N.G. Romanenko \\ Rostov State University of Economics (RSUE) \\ Rostov-on-Don, Russia \\ kafedra37@bk.ru
}

In order to understand the nature of legal nihilism it is important that no other national legal culture, considered by us as a complete result of historically accumulated cultural and practical legal experience, reflected in legal knowledge, traditions and skills, which constitute a stable and agreed socio-legal national reciprocity, is not actually unified and absolute.

The controversy of legal-cultural dominating idea is defined by its heterogeneity, variability, dynamics, need for social development renewal and improvement. Under these conditions it is impossible to speak about the presence of nationwide perceptions of fairness, equality, responsibility and freedom, the measures of which is defined by law.

\section{PROBLEM STATEMENT}

Based on this we can state that supporting a positive and respectful attitude towards rights and law from all of the subjects does not seem feasible, while negative attitude towards the current law amongst a certain group of individuals is an objective phenomenon. The latter, given its potential societal threat, which is caused by the negative attitude towards the commonly accepted in the community, should be monitored, controlled and neutralized in its extreme and radical examples. As previously noted by S.L. Frank, it is impossible to target legal action on nihilistically charged social groups, who view the destruction of commonly accepted values as the emergence of new ideas [1].

\section{RESEARCH QUESTIONS}

Thus, legal nihilism should be considered as a type of negative subjective attitude towards law, caused by a deliberate or intuitive perception of surrounding legal environment, as opposed to a psycho-physiological pathology. Therefore, nihilistic behavior towards law expands and becomes more radical during the crisis periods, as well as during the periods of radical reforms, when the law and order do not fulfil its social functions, and hampers social processes 
Based on the method of historical criticism, authors define due to the conservatism of its renewal mechanism. During the periods of stable societal development, legal nihilism exists in its latent form, and doesn't have a mass and uncontrollable character, neither does it cause destructive impact on the legal system as a whole.

Given this, it is important to highlight that negative and disrespectful attitudes towards law, which is reflected in rejecting the social value of law, do not mean a rejection of law by a subject or a social group in its variety of forms [2].

A nihilistic attitude towards law exists within the legal boundaries, but serves as evidence regarding the deviation from positive legal understanding in the direction of rejecting the social value of law and its potential regeneration. As pointed out by N.N. Voplenko, legal nihilism is a result disappointment from subjects towards their legal ideals, rule of law and feeling of fairness, which formulates a desire to exit the legal field of activity [3]. This, was also pointed out by S.S. Alekseev, who noted that legal nihilism is evident of disbeliefs in universality and reliability of law for the purpose of social problems resolution [4]. On the contrary to the renunciation of law, which more often than not is an irreversible process, legal nihilism can be reversed and be brought back to the norm.

This requires a complex of various (social, political, cultural, educational and legal) measures, which support the authority of law for a particular person or social group.

\section{PURPOSE OF THE STUDY}

The development of above-mentioned measures is only possible after an all-rounded theoretical research of legal nihilism and the discovery of the system of influential factors, as well as reverse impact of legal nihilism on the social system, which constitutes the aim of this study.

Detailed research is necessary for legal-psychological and legal-ideological formulation of legal nihilism. It is also essential to develop criteria for positive legal understanding, in order to picture the nature and criteria for deviation. However, first of all it is important to understand the actual definition of legal nihilism.

\section{RESEARCH METHODS}

Research methods are defined by the dialectical approach towards the legal nihilism phenomenon, which is seen in research of legal nihilism from the point of view of changing legal thought, given its form, development process, as well internal causes. Its essence is seen in moving towards understanding the legal nihilism, which in itself proves and deducts the process. We rely on the fact that if scientific perception is true in its content, this perception can translate into a form of understanding.

The use of comparative-legal methodology contributed towards separating legal nihilism, and other forms of deformed legal understanding, revealing national traits of nihilistic attitude towards law and comparison of studies of legal nihilism in Russia. and explain the specifics of legal nihilism theory, which attributes towards a historical period of scientific research, as well as sets out a common interconnecting characteristic.

Besides this, the research applies a number of common scientific (analysis, synthesis, modelling, induction, deduction, scientific disengagement, comparison, structural functionality, statics) and special legal (formal-dogmatic, formal-logical defining) methods.

\section{FINDINGS}

In order to achieve the aim of the study, let us define the constant specific characteristics of legal nihilism.

Legal nihilism is a subjective legal phenomenon, which is objectively supported by social factors, caused by the state and changing condition of social connections and common relations in the legal reality, and the need for a person to adapt to this reality. Such social adaptation is often impossible to implement based in the typical patterns of thinking and behavior in the legal sphere. Therefore, under the conditions of ever-changing historical situation, accumulated experience is revaluated, resulting in the devaluation of current understanding of law, as well as initiates a process of generating potential alternatives. This results in a negative perception of legal reality, as well as a reflective impact through the readiness amongst subjects to engage in a certain legal behavior.

Legal nihilism in all of its forms is reflected in negative evaluation or negative attitude towards processes implemented earlier, current or desired law, imposing a threat to action. A condensed characteristic of legal nihilism provided by a Hungarian legal scientist C. Varga states that legal nihilism acts as fuel or a dictatorship and reflects the threats of radical nihilistic expressions [5]. However, potential threat to security and stability of the legal system is present in all forms of legal nihilism.

Legal nihilism contains legal ideological component, which is reflected in the negative attitudes towards the desired or active legal ideas, theories, perceptions, understandings, as well as legal-psychological content, which is present in emotions, experiences and feelings. The latter, according to G.F. Shershenevich [6] is seen in the absence of feeling of lawfulness, which is the absence of motivation to abide the established laws (and other legal instructions) regardless of the conditions.

Legal nihilism has destructive as well as constructive forms of presence and existence. Since they only reflect the unity and controversy of various tendencies and processes in the legal reality and hence allow the subject to navigate in the everchanging socio-legal situations and creatively transform the current legal reality via critical rethinking and negative attitude towards outdated legal phenomena. Only in this case, we can talk about particular constructive elements in the negative legal instructions, which evolved as a result of nihilistic perception of law. 
Legal nihilism is formed under the influence of various social factors on individual and societal legal understanding. Dependent on this, legal nihilism reveals itself in the legal reality. This results in plurality of forms of legal nihilism, which can be classified based on various states. Based on the content we should highlight the theoretical and practical legal nihilism, based on subjective criteria - individual and aboveindividual (group and communal), based on evaluation and utilized tools - common and scientific legal nihilism, professionality criteria distinguishes between professional and non-professional legal nihilism, time criteria allows to highlight stable and timely displays of nihilistic attitudes towards law, based on spatial criteria, the investigated phenomenon can be split between national and global (multinational) legal nihilism, based on the level of societal threat we can focus on latent and radical legal nihilism, based on the character and intensity of denial of social significance of law, let us highlight passive and active legal nihilism.

Legal nihilism has a complex legal nature and structure, that includes content and form, as well as inter-systematic and cross-systematic connections, which support its relation with other elements of legal understanding and understanding of law as a whole. This particular content supports the specifics of the investigated phenomenon, as the form of legal nihilism can be similar to other components of deformed legal understanding.

Nihilistic relation with law cannot be separated from legal understanding, as it evolves during the process of carrying out its evaluative function and hence possesses the traits that are attributable to legal understanding, such as internal dialogism, intentionality, controversy and dynamics. This statement is based on the commonly accepted psychological state of mind as unity of knowledge and perception. It is important to point out that the presence of legal nihilism proves that legal understanding is not a mirror image of social objects in the legal sphere. Moreover, as part of the evaluative function of legal understanding, a negative perception to various elements of legal reality can evolve.

Legal nihilism is a subjective phenomenon, closely related to its subject, and represents a personally motivated, intuitive or supported by experience acceptance of inability of law to support social values. We do not agree with studies that evaluated nihilistic attitude towards law from disabled individuals [7]. Since the disabilities were caused by physiological factors, as opposed to social ones. A human is able to understand only those legal instructions that ones mind can process. The impact of subconscious on the formulation of nihilistic perception is considered secondary.

Legal nihilism not only arises during the process of conscious perception and evaluation of legal reality, but also under the influence of subconscious elements that are organically related to te legal understanding. The following statement is based on the commonly accepted thesis regarding dialectical unity of ideological and psychological elements of legal understanding, as well as the results of scientific research and the influence of subconscious on the legal understanding. Amongst these elements E.A. Belkanov highlights basic stereotypes (for instance lawfulness and fairness), primary and secondary gaps in legal understanding, related to the absence of information about legal reality, rudimental legal instructions, based on the ideas, perceptions and instructions about the outdated legal phenomena [8].

Legal nihilism is formulated under certain historical conditions and hence given the changes in these conditions, the instances of legal nihilism can be overcome. This is partly explained by the fact that a certain type of historical legal understanding (medieval, bourgeois, socialist and etc.) can correlate with certain features of legal nihilism, which transform or disappear completely during the transition period. It is important to highlight that transition periods can simultaneously interact with multiple types of legal understanding and as a result of variety amongst nihilistic behaviors. As a result of this variety, their simultaneous action, given their specific attributes in a certain historic setup, results in radicalization, as well as strengthening of negative determinant on legal behavior amongst subjects.

We should point out that understanding of legal nihilism is only possible given the aggregate of all existing factors, some of which can be viewed as deformation of legal understanding.

Modern legal literature highlights positive and antipositive (defective) legal understanding. However, there is no mention of concrete criteria distinguishing the two. We believe that the main justification for such segregation should be the respect towards law and order, which in this study is viewed as high social value of law for an individual and community, reflected in the legal setup of subject to abide the law.

Respectful attitude towards law is developed based on the dialectical unity of experience, confidence and judgement of independent social significance of law and the necessity to abide the rules under all circumstances. The presence of respect for law is a legal instruction and characteristic of positive legal understanding. It becomes an essential element of values orientation for a group and individual.

Positive, can only be attributed to individual or above-individual legal understanding that includes respect for law as an essential element. The indicator of the strength of this respectful attitude is the presence of the need to abide the legal norms. However, we would like to point out that entirely rational understanding of value of law, equally to entirely emotional understanding should not be considered positive. The absence of a respectful attitude towards the law, is an indicator of deformed legal understanding, which also includes legal nihilism.

The gaps in the theory of deformed legal understanding and legal nihilism as a whole, result in a very broad interpretation. Thus, the studies of modern legal scientists, often assign intended breach of law and other normative-legal acts as acts of legal nihilism. In this case there is a mixup between actual crime and legal nihilism. The issue of controversial or mutually exclusive legal acts is also included. Often legal nihilism is conveyed as imperfection of legislature, and even breaches in sovereignty and separatist ideology [9].

We believe that modern legal science is full of stereotypical perceptions regarding legal nihilism, which has 
no relation to the essence of the problem. In fact, it is hard to agree that legal nihilism as a phenomenon only arises during the crises of social relations. In fact, during the periods of the crises, the forms of legal nihilism tend to change and gain more radical destructive character.

Another common scientific stamp can be observed in viewing the breaches in law and crime as types of nihilistic behavior. Majority of modern studies, devoted to legal nihilism, is based on the belief that a person committing a crime is in fact a nihilist. In this relation, it is appropriate to quote V.N. Kartashov, as he mentioned that legal understanding is a determinant of behavior amongst individuals, but the behavioral component characterizes one of the sides of legal culture, and not legal understanding [10]. We can also say that evaluative-instructive complex of legal understanding bears the main burden of supporting legal behavior. The fact that defects in legal understanding lie in the sphere of attitude towards law, has been proven multiple times by soviet scientists [11]. However, the person committing a crime in comparison to a legal nihilist, breaches the scope of law and is in possession of regenerated legal understanding, as opposed to defective one.

\section{CONCLUSION}

All of the above-mentioned allows us to conclude that the studying of the theory of legal nihilism opens up new horizons of legal understanding and allows as to identify significant gaps in legal science. Thus, the investigated phenomenon brings back the unity of biological, psychological and sociolegal essence. Addressing the problems of legal nihilism shows that a person is not only an object of state-legal influence, but also is an active creative subject, forming a personal reality, with its institutional structures.

Only on the basis of individual-centered model of legal science it is possible to understand law and relation of subjects with their psychological and socio-cultural abilities. Activities of these subject compose the political system of the society. Legal instructions, deprived of value-based attitude towards a particular individual, one's rights and liberties, undeniably cause disrespectful attitude on the individual and societal levels, as well as opposes the hierarchy of social values [12].

Based on the above-mentioned, let us formulate authors' definition of legal nihilism, which can be defined as intuitive negative relation towards law and legal processes, which emerges in the society as a result of intellectual-emotional perception of individual in the process of carrying out evaluative function of legal understanding and is not accompanied by the presence of crime planning [13].

All of the above-mentioned allows us to conclude that the most effective way to prevent legal nihilism is to develop a complex of events to formulate a respectful attitude towards law on the national project level. The following project should become the logical and historical continuation of the fight for freedom, which was started by Russian legal scientists at the end of the 19th century, including scientific research about common characteristics of value-based attitude towards law, as part of the aggregated approach towards formulating a personal and societal value-legal reference point in order to improve the social significance of law.

\section{References}

[1] S.L. Frank, Ethics of nihilism, Moscow, 1990, p.81.

[2] N.N. Alekseev, The General theory of law, Simferopol, 1919, p.153.

[3] N.N. Voplenko, "Legal understanding of a lawyer and the problem of its deformation", Problems of theory and government. Saratov, vol. 3(12), p.66, 2001.

[4] S.S. Alekseev, Law on the break of centuries, Moscow, 2000, p.188.

[5] Ch. Varga, The riddle of law and legal understanding, St.Petersburg, 2015, p.241.

[6] G.F. Shershenevich, Feeling of lawfulness, Selected, Moscow, 2016, p.460.

[7] K.G. Fedorenko, Legal nihilism, Dissertation, Moscow, 2003, p.75.

[8] E.A. Belkanov, Structure and functions of legal understanding, Dissertation, Ekaterinburg, 1996, pp.10-14.

[9] V.N. Protasov, Theory of law and government, Problems of theory in law and government, Moscow, 1999, p.91.

[10] V.N. Kartashov, Theory of legal system of society: learning in 2 vols, vol.2, Yaroslavl, 2006, p.7.

[11] G.Kh. Efremova, "The features of evaluative-normative system of personality of young legal offenders and problems of legal upbringing", Legal understanding and legal upbringing for young individuals, Moscow, 1978, p.63.

[12] T.V. Shatkovskaya, N.G. Romanenko, Y.A. Naumenko, E.A. Parshina. "The problem of individualization of legal entities in terms of innovative development of the Russian Federation and the European Union Economy", European Research Studies Journal, vol.20, pp.162-171, 2017.

[13] Tatiana V. Shatkovskaya, Tatiana V. Epifanova, Natalia G. Vovchenko, Irina S. Maslova, "Goals and Interests in the Law of the Digital Age, Digital Economy: Complexity and Variety vs. Rationality", Springer Nature Switzerland AG, pp. 899-907, 2020. 